\title{
AN ALTERNATIVE METHOD OF PREVENTING COASTAL EROSION IN KERASIAN ISLAND
}

\author{
Yulian Firmana Arifin ${ }^{1)}$, Gusti Ihda Majaya ${ }^{2)}$, Muhammad Noor Azhari'), and Ellyn \\ Normelani $^{3)}$
}

1) Civil Engineering, University of Lambung Mangkurat, Banjarbaru, South Kalimantan

2) Environmental Eng., Univ. of Lambung Mangkurat, Banjarbaru, South Kalimantan

3) Geography, University of Lambung Mangkurat, Banjarmasin, South Kalimantan

\section{y.arifin@ulm.ac.id}

\begin{abstract}
In 2013, Kerasian Island experienced erosion, which caused the coastline to shift \pm $100 \mathrm{~m}$ from the initial condition. In some places, the retaining wall has been damaged so that it does not function properly. An effort is needed so that the beach does not experience abrasion and is safe for the activities of residents or tourists who come there. Before deciding on an alternative, first of all, is to choose from many erosion prevention methods that are suitable for the beach conditions there. The selection was conducted using the Analytical Hierarchy Process (AHP) method. Based on the AHP method, groin combined with mangrove planting is a suitable method to be applied on Kerasian Island. The groin design refers to the Pd T-04-2005-A guidelines issued by the Indonesian Ministry of Public Works. The dimensions of the design results and groin material used are explained in detail in the paper.
\end{abstract}

Keywords: Kerasian Island, coastal erosion, groin, mangrove

\begin{abstract}
ABSTRAK
Tahun 2013, Pulau Kerasian mengalami erosi yang mengakibatkan garis pantai berpindah $100 \mathrm{~m}$ dari kondisi awalnya. Di beberapa tempat, dinding penahan tanah rusak sehingga tidak berfungsi dengan baik. Suatu usaha diperlukan agar pantai tidak mengalami abrasi dan aman untuk berakrivitas penduduk dan turis yang datang ke sana. Sebelum memutuskan alternatif, pertama-tama, memilih dari beberapa metode untuk mencegah erosi pantai dengan metode Analytical Hierarchy Process (AHP). Berdasaran metode tersebut, groin yang dikombinasi dengan tanaman mangrove cocok diaplikasikan di pantai pulau Kerasian. Desain groin berdasarkan PdT-04-2005 yang dikeluarkan oleh Kementerian Pekerjaan Umum Indonesia. Dimensi dan material groin yang digunakan dijelaskan detil dalam paper.
\end{abstract}

Kata kunci: Pulau Kerasian, erosi pantai, groin, mangrove 


\section{INTRODUCTION}

Indonesia has a tough challenge to maintain the condition of the beach, especially from abrasion. This is because Indonesia has many islands and a coastline of $99,093 \mathrm{~km}$ (the longest in the world after Canada). Coastal abrasion has become a national issue where data from 2011-2016 recorded 45 abrasion events and tidal waves that occurred throughout Indonesia, which resulted in damage to housing, death, and displacement (BNPB, 2018). Marfai (2011) reported that erosion along the coast in Semarang from 19721992 was $461 \mathrm{~m}$ or an average of $23.05 \mathrm{~m}$ per year. Hegde (2010) noted the rate of erosion is different in each country, for example, USA 0.3-0.6 m per year, China
16-56 m per year, and Nigeria 25-30 m per year.

In 2017, Indonesia reported 16,056 of the 17,504 islands that have been named to the United Nations (Kemendagri.go.id data). One of the small islands discussed in this article is Kerasian Island. This island is one of the areas located in the south of Pulau Laut, Kotabaru Regency, South Kalimantan Province (Figure 1). The island has an area of 5.75 square kilometers and is inhabited by approximately 2542 people. The population generally works as fishermen. On this island, housing is parallel to village roads and coastlines (Hidayat et al., 2016) so that the coastline is significant and must be maintained.

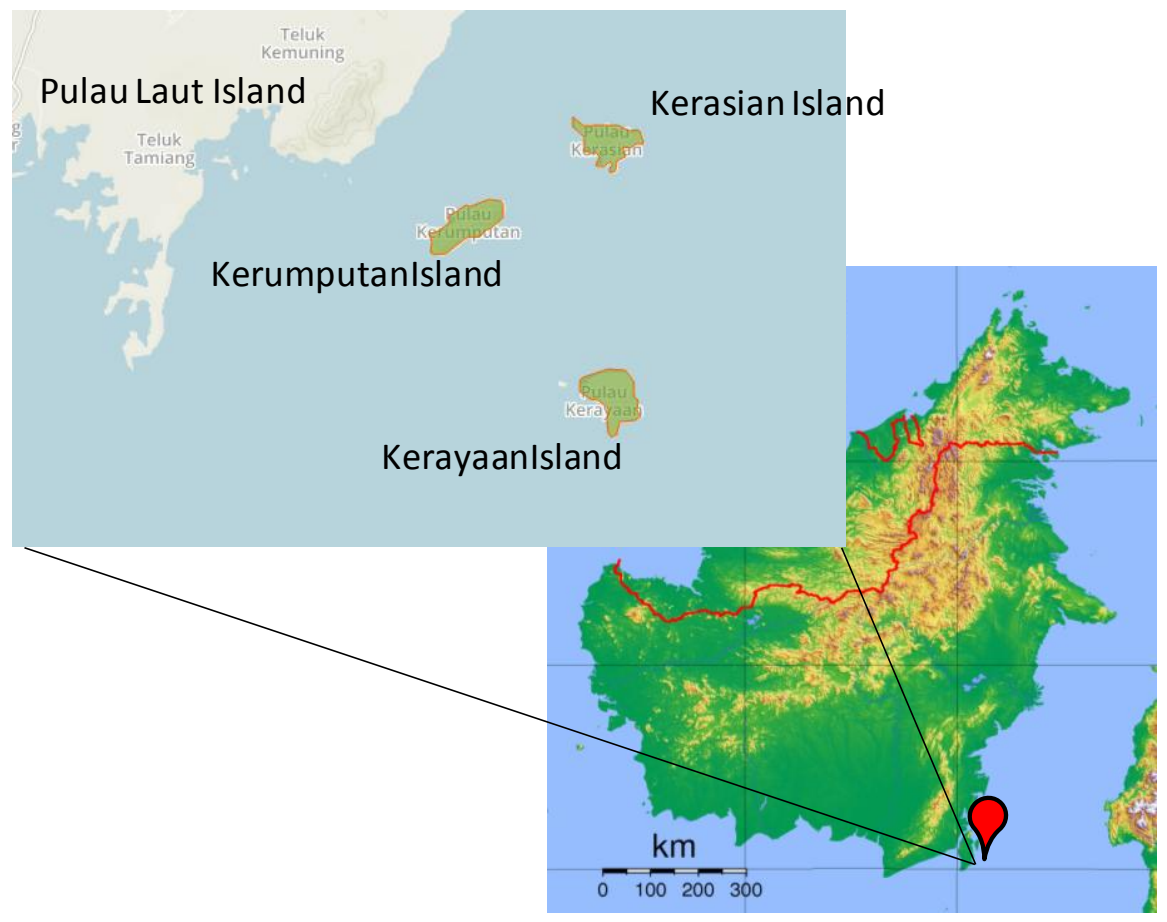

Figure 1. Kerasian Island and Other Islands Around it 
Although efforts to prevent erosion have been carried out, Kerasian Island continues to experience abrasion. The disruption of the initial conditions drove damage to the coastline due to this abrasion. The built-in retaining wall is unable to overcome the abrasion. To anticipate more severe damage, a solution that is suitable for the area needs to be determined. Whatever it must be able to withstand wave attacks, and reduce the wave energy that reaches the beach so that no abrasion occurs.

Chang et al. (2018) reported that human activities, including the construction of hard structures along the coastline, had changed the balance of the coast and resulted in erosion. So that historical data on shoreline changes is essential for planning coastal regions. Pilkey and Cooper (2012) investigated many alternative shoreline erosion control devices and classified these devices in devices placed in the water and devices placed on the beach/dunes, including groins. The primary purpose of the groin is to move sediment that is moving alongshore in the littoral current. Groin causes downdrift beach erosion, often creating currents that are harmful to swimmers, and causing loss of offshore sediment, and blocking activity on the beach, for example walking (Pilkey and Cooper, 2012). However, in many circumstances, groins have functioned effectively and stabilized an eroding beach without seriously harming adjacent areas (CSE, 2013)

Hedge (2010) reports that efforts to prevent coastal erosion move from hard methods to soft, innovative, and proactive methods. Hard methods tend to harm the beach, such as down-drift, expensive, and fewer aesthetics. However, preventing erosion with soft methods such as vegetation is not very successful without hard methods such as structural wave dumping as reported by Hall and Ludwig more than 40 years ago. Faulkner (2010) states that the combination of hard method and vegetation should be considered when planting of vegetation alone will not solve the erosion problem. This paper discusses alternative methods for preventing erosion on Kerasian Island by a combination of hard methods (i.e., groin) and soft methods (i.e., mangrove).

\section{LITERATURE REVIEW}

\subsection{Classification of coastal buildings}

Seawalls are almost similar to revetments (coastal protection structures that are made parallel to the coast and usually have a sloping surface), which is 
made parallel to the beach, but seawalls have relatively steep or curved walls. Types of seawall, among others (Triadmodjo, 2008):

1. Concrete curve-face seawall used to withstand high waves and reduce wave energy.

2. Particular combination curvestepped seawall used to withstand high waves and reduce wave energy.

3. Concrete stepped seawall, used to defend from moderate waves.

4. Rubble mound seawall used to defend the coast from hard waves.

A breakwater is a building used to protect water areas from wave interference. Breakwaters can be divided into two types, namely breakwater wave breakers, and offshore breakwaters. Breakwaters can be divided into three types (Triatmodjo, 2008), namely:

1. Oblique side type breakwaters, made from piles of natural stone, concrete blocks, a combination of broken stones and concrete blocks, artificial stone made of concrete with special shapes such as tetrapods, quadripods, tribars, and dolos.
2. Vertical side-type breakwaters, made of concrete caisson, vertically arranged mass block walls, steel sheet pile cells inside which are filled with stone, steel or concrete sheet piles, etc.

3. Mixed type breakwaters, made used in deep water, and if the use of side and upright side breakwaters is not economical. The material used is a combination of the two previous types.

\subsection{Calculation of Beach Structure}

A Groin is a coastal protection structure that is usually made perpendicular to the coastline and serves to hold sediment transport along the coast so that it can reduce or stop erosion. In general, the length of the groin is $40 \%$ to $60 \%$ of the average width of the surf zone, and the distance between groins is 1 to 3 times the length of the groin (Triatmodjo, 2008). Groins have several types; there are straight type, T type, or L type. Selecting the type of groin depends on the use and planning needs. The selected plan wave height is the maximum wave height that may occur at the job site.

$\mathrm{Hb}=0.78 \mathrm{ds}$

where:

$$
\mathrm{Hb}=\text { breaking wave height }(\mathrm{m})
$$


ds = water depth at building site (m)

Wave height can be calculated with the following formula:

$$
\begin{aligned}
& \frac{\mathrm{Ru}}{\mathrm{H}}=\mathrm{f}(\mathrm{Ir}) \\
& \mathrm{Ir}=\frac{\operatorname{tg} \theta}{\left(\frac{\mathrm{H}}{\mathrm{LO}}\right)^{0,5}}
\end{aligned}
$$

where:

$$
\begin{aligned}
& \mathrm{Ru}=\text { wave height }(\mathrm{m}) \\
& \mathrm{H} \quad=\text { come wave height }(\mathrm{m}) \\
& \mathrm{Ir} \quad=\text { Iribarren Numbers } \\
& \theta \quad=\text { angle of the breakwater side } \\
& \mathrm{f}(\mathrm{Ir})=\text { Wavepan Coefficient } \\
& \mathrm{Lo} \quad=\text { wavelength } 1.56 \mathrm{~T} 2(\mathrm{~m}) \\
& \mathrm{Q} \quad=\text { wave period (seconds) }
\end{aligned}
$$

The spillway elevation is calculated using the following formula:

Spillway elev. $=\mathrm{DWL}+\mathrm{R}_{\mathrm{u}}+\mathrm{F}_{\mathrm{b}}$

where:

$\mathrm{DWL}=$ design water level

$\mathrm{Fb}=$ free board $(0.5-1.5 \mathrm{~m})$

Detailed calculation procedures are described in the Pd T-04-2005-A guidelines issued by the Indonesian Ministry of Public Works in the next section.

\subsection{Analytical Hierarchy Process (AHP) method}

The principle of the AHP method is to simplify a complex problem that is not structured, strategic, and dynamic into its parts, and organize in a hierarchy. The level of importance of each variable is given a numerical weight and is subjective about the significance of the variable relative to other variables.

Table 1 shows an example of the assessment criteria used in AHP method. This method has been widely used to determine suitable construction options to prevent coastal erosion (Plangiten, 2013; Chen et al., 2013; Mangare, 2016; ).

Table 1. Assessment Criteria and Alternative AHP methods

\begin{tabular}{cl}
\hline Value & \multicolumn{1}{c}{ Remarks } \\
\hline 1 & $\begin{array}{l}\text { Assessment Criteria and } \\
\text { Alternative AHP methods } \\
\text { Criteria/alternative A is as } \\
\text { important as } \\
\text { criterion/alternative B } \\
\text { A is slightly more important } \\
\text { than B } \\
\text { A is clearly more important } \\
\text { than B } \\
\text { A is absolutely more } \\
\text { important than B } \\
\text { When in doubt between two } \\
\text { adjacent values }\end{array}$ \\
\end{tabular}

Source: Mangare, 2016

\section{METHODS}

The data needed include secondary and primary data. Secondary data was obtained from several related institutions, which included hydro-oceanographic data consisting of wind and tidal data, which was obtained from the Stagen 
Meteorological, Climatological, and Geophysical Agency, Kotabaru.

Primary data obtained from the results of field investigations through observations and interviews and test results in the laboratory. The field data includes bathymetry, topography and wave data, and laboratory data includes data on sediment gradation and soil mechanics.

All data were then analyzed, including wind, wave, tidal, and sediment analysis. The next procedure was to conduct an alternative study of coastal abrasion treatment, which includes biotic treatment (i.e., mangrove) and abiotic (i.e., groins, jetties, offshore breakwaters, and revetment). The selection was conducted using the Analytical Hierarchy Process (AHP) method.
The last procedure was the construction design, including the shape, dimensions, strength, and number.

\section{RESULT AND DISCUSSION}

\subsection{Wind Analysis}

Distribution of wind data based on speed and direction was intended to determine the direction of the dominant wind that produces the dominant wave. The percentage of influential wind events are originated from the west $(12.47 \%)$, southwest $(7.4 \%)$, southeast $(8.83 \%)$, and the largest from the south (50.58\%) (Figure 2). So the dominant wind direction is south with a maximum wind speed of 33 knots or $16.962 \mathrm{~m} / \mathrm{s}$. Winds coming from the west, southwest, and southeast affect the analysis of wave forecasting.

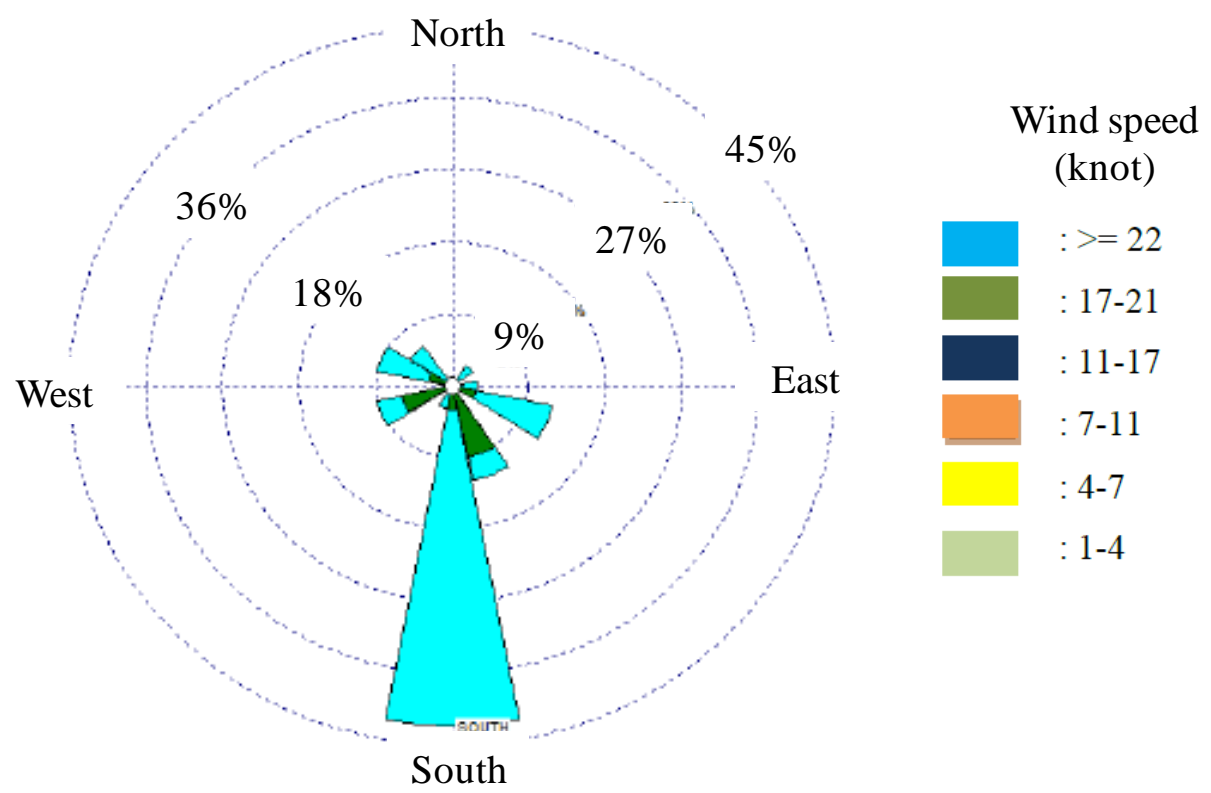

Figure 2. Wind rose 


\subsection{Wave Analysis}

The height and wave period are calculated using a wave forecasting graph after the effective average fetch (Figure 3), and wind speed is known. From the results of the analysis, it was found that significant wave height $\left(\mathrm{H}_{33}\right)$ and significant period $\left(\mathrm{T}_{33}\right)$ were $0.87 \mathrm{~m}$ and 3.3 seconds, respectively. Furthermore, the height and depth of the breaking wave were calculated with the results of $1.008 \mathrm{~m}$ and $1.29 \mathrm{~m}$, respectively.

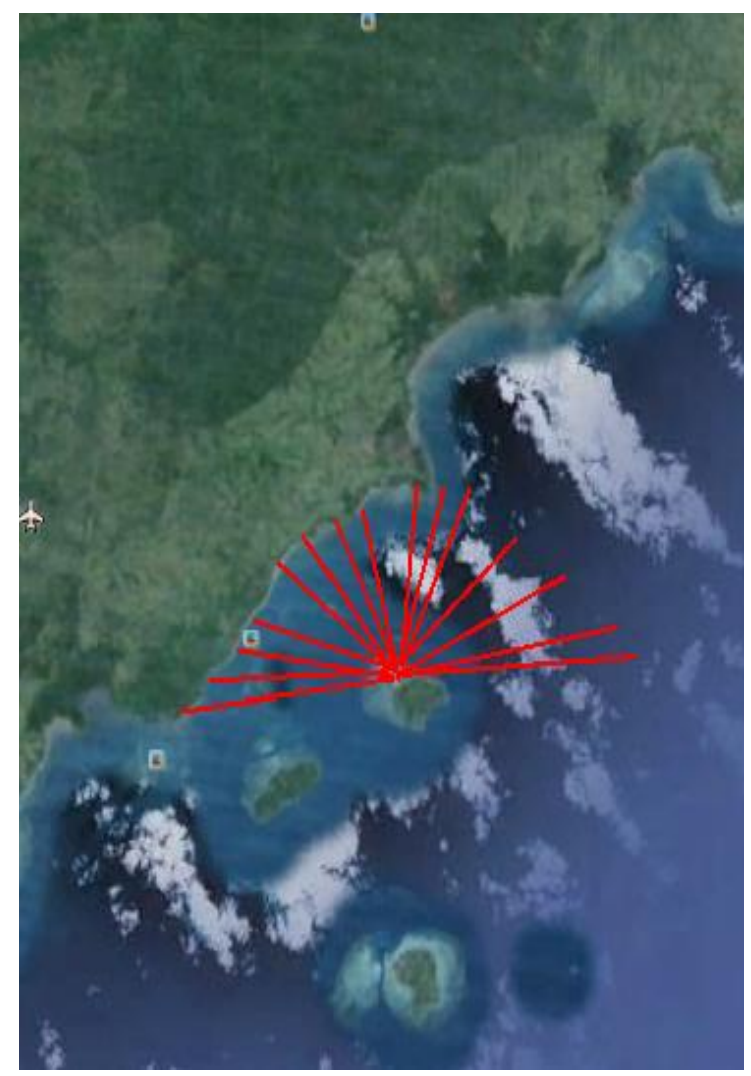

Figure 3. The effective average fetch

\subsection{Tidal Analysis}

Tides are predicted using the previous year's tidal data (Figure 4). Tidal data were obtained from the Stagen Meteorology, Climatology and Geophysics Agency, Kotabaru Regency. Water level obtained from tidal data are HHWL 2.70 m, MHWL $2.27 \mathrm{~m}$, MSL $1.39 \mathrm{~m}$, MLWL $0.51 \mathrm{~m}$, LLWL $-0.1 \mathrm{~m}$. Where HHWL is the highest high watel level, MHWL is mean high water level, MSL is mean sea level, MLWL is mean low water level, and LLWL is the lowest low water level.

\subsection{Bathymetric and Topographic Map}

Figure 5 shows bathymetric and topographic map of the Kerasian island where erosion was occured. The cross sections of the shore experiencing erosion(i.e., A-A', E-E', and K-K') are shown in Figure 6. The figure shows that the worst erosion occurred in the eastern part of the coast (K-K').

\subsection{Sediment and Soil Data}

The median grain size $D_{50}$ is the grain size at which $50 \%$ of the accumulated sample weight. Based on grain size distribution curve obtained $\mathrm{D}_{50}$ of sediment is $0.43 \mathrm{~mm}$. The sediment is classified as medium sand.

The soil data used in this article is the soil obtained in the surface (i.e., 0-0.5 $\mathrm{m}$ depth). The soil was investigated in Soil Mechanic Laboratory of ULM. 


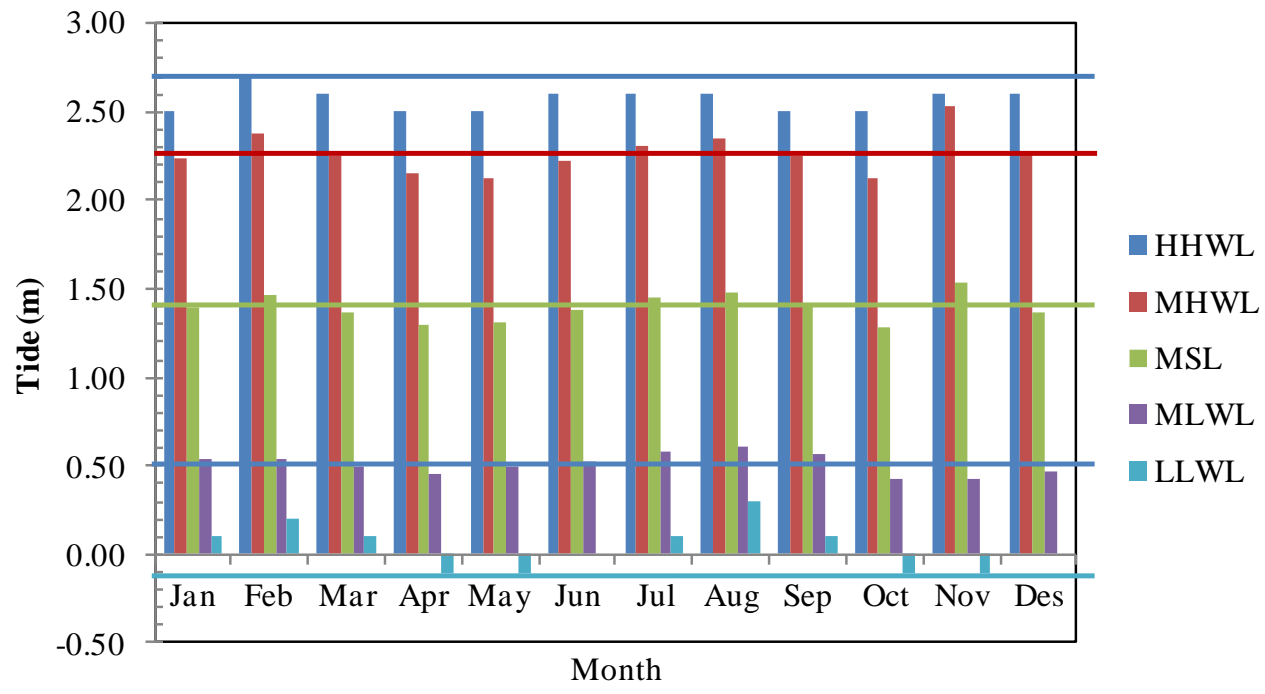

Figure 4. Tidal Graph

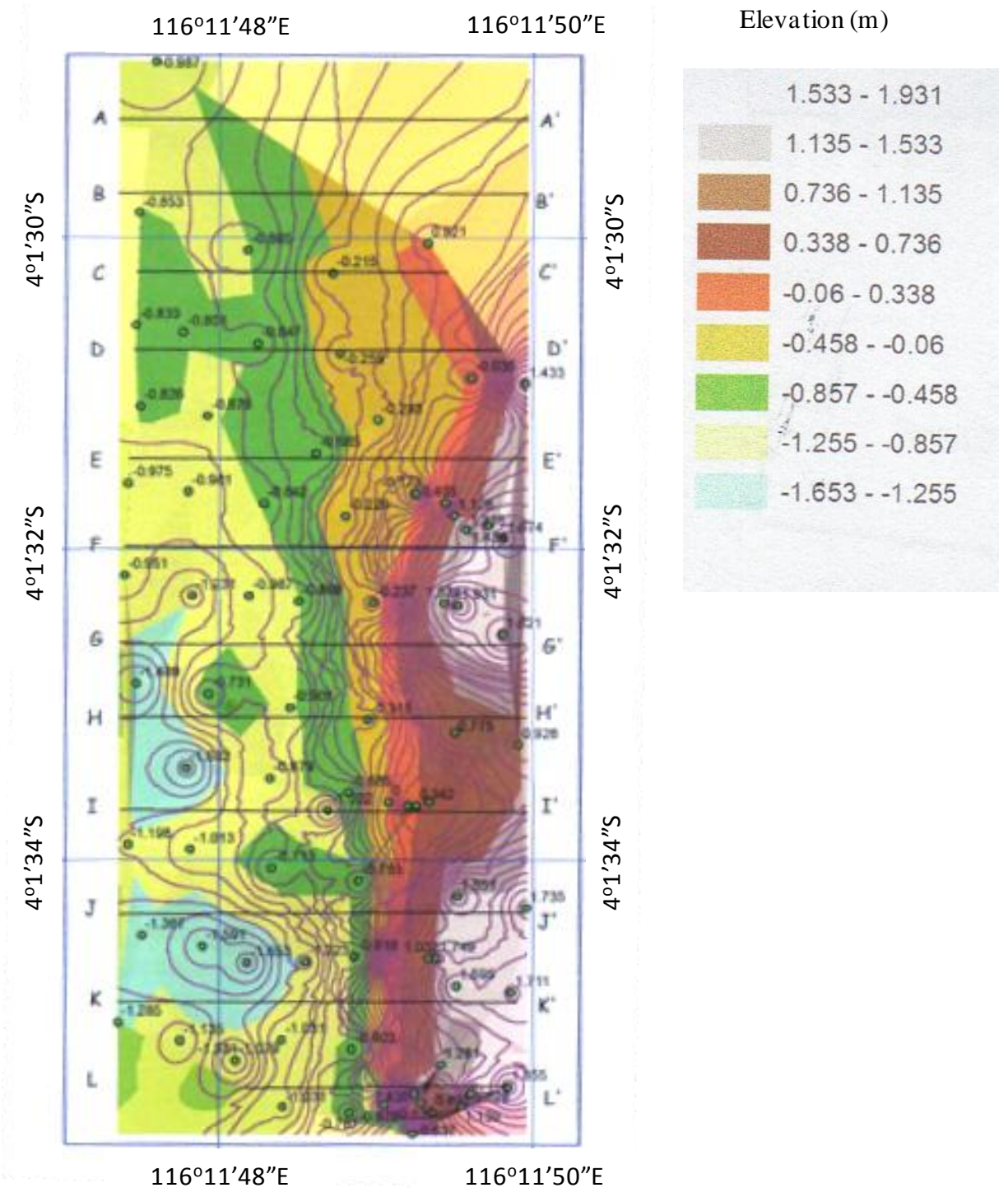

Figure 5. Bathymetric and Topographic Map 


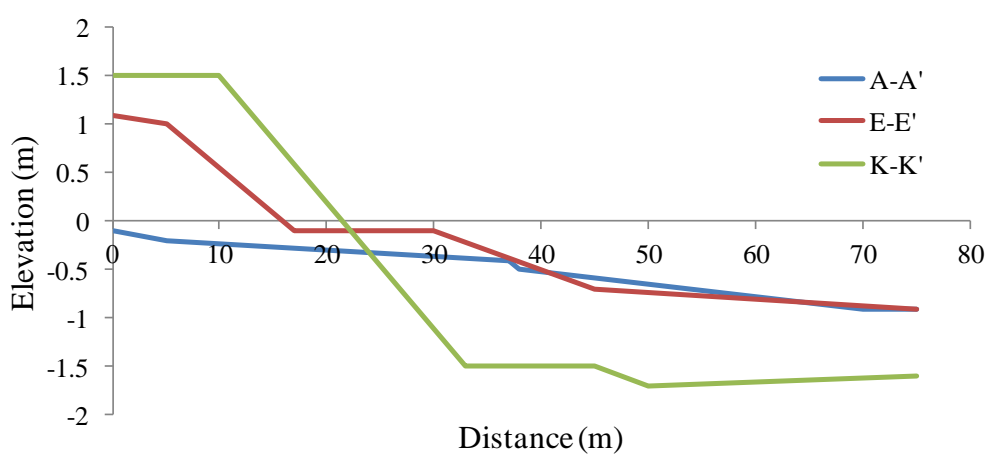

Figure 6. Cross Sections of the Topographic Maps

The soil properties are summarised as followed:

$$
\begin{aligned}
\mathrm{G}_{\mathrm{s}} & =2.68 \\
\mathrm{c} & =0 \\
\gamma_{\mathrm{d}} & =1.69 \mathrm{t} / \mathrm{m}^{3} \\
\phi & =33.38^{\circ}
\end{aligned}
$$

Using Terzaghi equation, the soil has ultimate bearing capacity of $247 \mathrm{ton} / \mathrm{m}^{2}$.

\subsection{Alternative Selection using AHP Method}

Before deciding on an alternative, first of all, is to choose from many erosion prevention methods that are suitable for the beach conditions there. The selection was conducted using the Analytical
Hierarchy Process (AHP) method. This method has been widely used to determine suitable construction options to prevent coastal erosion (Plangiten, 2013; Chen et al., 2013; Mangare, 2016; ).

AHP criteria used are those that have a significant influence on the system. The criteria set for the selection include waves, erosion, abrasion, sedimentation, and the environment. In this article, the structure is chosen from three alternatives of coastal construction (i.e., seawall, breakwater, and groin).The total weighting of the criteria and alternative relationship matrix is shown in Table 1.

Table 2. Matrix of alternatives and criteria relationship

\begin{tabular}{ccccc}
\hline Criteria & Seawall & Breakwater & Groin & Jetty \\
\hline Wave & 0.185 & 0.156 & 0.659 & 0.659 \\
Erosion & 0.429 & 0.143 & 0.429 & 0.429 \\
Abrasion & 0.429 & 0.143 & 0.429 & 0.429 \\
Sedimentation & 0.125 & 0.125 & 0.125 & 0.125 \\
Environment & 0.143 & 0.429 & 0.429 & 0.429 \\
\hline Total & 1.311 & 0.996 & 2.071 & 2.071
\end{tabular}


From the AHP method, the highest score is groin. Based on this score, a groin type of coastal structure will be designed. The groin is beach protection by means of hard solution, to maximize the function of the construction, then combining hard solutions with soft solutions in the form of mangrove planting.

\subsection{Structural Design}

\subsubsection{Design water level}

$\mathrm{DWL}=\mathrm{MHWL}+\mathrm{S}_{\mathrm{W}}+\mathrm{SLR}=2.63 \mathrm{~m}$

where:

$\mathrm{DWL}=$ design water level

$\mathrm{Sw}=$ wave set-up

SLR = sea level rise due to global warming

\subsubsection{Crest elevation}

Crest elevation was calculated using the following formula:

Crest elevation $=\mathrm{DWL}+\mathrm{R}_{\mathrm{u}}+$ freeboard where:

$\mathrm{R}_{\mathrm{u}}=$ wave run up

Crest elevation $=4.04 \mathrm{~m} \approx 4.10 \mathrm{~m}$

\subsubsection{Armour stone}

Armour stone was calculated using Hudson Equation:

$$
\begin{aligned}
& \mathrm{W}=\frac{\gamma_{\mathrm{r}} \mathrm{H}^{3}}{\mathrm{~K}_{\mathrm{D}}\left(\mathrm{S}_{\mathrm{r}}-1\right)^{3} \cot \theta} \\
& \mathrm{S}_{\mathrm{r}}=\frac{\gamma_{\mathrm{r}}}{\gamma_{\mathrm{w}}}
\end{aligned}
$$

where:

$$
\begin{aligned}
\mathrm{W}= & \text { the weight of armour stone } \\
& \text { (ton of } \mathrm{kg} \text { ) } \\
\gamma_{\mathrm{r}}= & \text { the volumetric weight of } \\
& \text { stone }\left(\mathrm{t} / \mathrm{m}^{3}\right) \\
\gamma_{\mathrm{w}}= & \text { the volumetric weight of sea } \\
& \text { water }\left(\mathrm{t} / \mathrm{m}^{3}\right) \\
\mathrm{H}= & \text { the design wave height at the } \\
& \text { toe of the structure (m) } \\
\theta= & \text { the angle of revetment with } \\
& \text { the horizontal }\left({ }^{\circ}\right) \\
\mathrm{K}_{\mathrm{d}}= & \text { a dimensionless stability } \\
& \text { coefficient }
\end{aligned}
$$

It is obtained $W=159 \mathrm{~kg} \approx 160 \mathrm{~kg}$

4.7.4 Thickness of the protective layer (t1)

$\mathrm{t}_{1}=\mathrm{n}_{\mathrm{t}} \mathrm{k}_{\Delta}\left(\frac{\mathrm{W}}{\gamma_{\mathrm{r}}}\right)^{1 / 3}=0.9 \mathrm{~m}$

where:

$$
\begin{aligned}
& \mathrm{n}_{\mathrm{t}}=\text { number of stone layer } \\
& \mathrm{k}_{\Delta}=\text { layer coefficient }
\end{aligned}
$$

\subsubsection{Secondary stone}

$\frac{\mathrm{W}}{20}=0.0795$ ton $=79.5 \mathrm{~kg} \approx 80 \mathrm{~kg}$

The thickness of the protective layer $\left(\mathrm{t}_{2}\right)$ :

$$
\mathrm{t}_{2}=\mathrm{n}_{\mathrm{t}} \mathrm{k}_{\Delta}\left(\frac{\mathrm{w}}{\gamma_{\mathrm{r}}}\right)^{1 / 3}=0.75 \mathrm{~m}
$$

\subsubsection{Core layer}

$$
\mathrm{W}=\frac{\mathrm{W}}{200}=0.8 \mathrm{~kg}
$$

\subsubsection{Groin peak width

$$
\mathrm{B}=\mathrm{n}_{\mathrm{p}} \mathrm{k}_{\Delta}\left(\frac{\mathrm{w}}{\gamma_{\mathrm{r}}}\right)=0.895 \mathrm{~m} \approx 1.00 \mathrm{~m}
$$




\subsubsection{Toe protection height, width, and weight}

Using $\mathrm{r}$ and $\mathrm{H}_{\mathrm{D}}$, toe height $=0.825 \mathrm{~m}$.

$\mathrm{B}=2 \mathrm{HD}$ to $3 \mathrm{HD}$, used $2 \mathrm{H}_{\mathrm{D}}=2.016 \mathrm{~m}$.

Weight of material $=0.5 \mathrm{~W}=80 \mathrm{~kg}$.

\subsubsection{Groin structure}

The design of the groin structure based on the calculation result is shown in Figure 7. Using Pd T-04-2005-A manual and the calculation steps suggested by Triatmojdo (2008), the dynamic wave force, dynamic wave moment, and hydrostatic force were calculated and used to analyze the moment and horizontal forces acting on the groin. The result are: Vertical force $(V)=140.650 \mathrm{t}$, Horizontal force $(H)=29.074 \mathrm{t}$, Resisting moment $\left(\mathrm{M}_{\mathrm{r}}\right)=1733.264$ t.m, Overturning moment $(\mathrm{Mo})=73.047 \mathrm{t} . \mathrm{m}$

\subsubsection{Bearing capacity of soil}

Soil data used in the calculation are:

$$
\begin{aligned}
\phi & =33.38 \\
\mathrm{~N}_{\mathrm{c}} & =50.2 \\
\mathrm{~N}_{\mathrm{q}} & =34.4 \\
\mathrm{~N}_{\gamma} & =32.6 \\
\mathrm{H} & =0.5 \text { meter } \\
\mathrm{c} & =0 \mathrm{~kg} / \mathrm{cm}^{2} \\
\gamma & =1.69 \mathrm{t} / \mathrm{m}^{3}
\end{aligned}
$$

Active earth pressure coefficient:

$\mathrm{Ka}=\tan ^{2}\left(45-\frac{\emptyset}{2}\right)=0.290$

Active earth pressure:
$\mathrm{Pa}=\frac{1}{2} \mathrm{Ka} \gamma \mathrm{Ht}^{2}=0.614$ ton $/ \mathrm{m}$

Eccentricity:

$\mathrm{e}=\frac{\mathrm{B}}{2}-\left(\frac{\sum \mathrm{MV}-\sum \mathrm{MH}}{\sum \mathrm{V}}\right)<\frac{\mathrm{B}}{6}$

$\mathrm{e}=1.918<3.08$

Maximum and minimum pressure:

$\mathrm{q}_{\min }=\frac{\sum \mathrm{V}}{\mathrm{B}} \times\left(1-\left(\frac{6 \mathrm{e}}{\mathrm{B}}\right)\right)=3.04 \mathrm{t} / \mathrm{m}^{2}$

$\mathrm{q}_{\max }=\frac{\sum \mathrm{V}}{\mathrm{B}} \times\left(1+\left(\frac{6 \mathrm{e}}{\mathrm{B}}\right)\right)=13.03 \mathrm{t} / \mathrm{m}^{2}$

Efektive width:

$B^{\prime}=B-2 e=14.66 m$

Bearing capacity factor:

$\mathrm{F}_{\mathrm{cd}}=1+0.4\left(\frac{\mathrm{Df}}{\mathrm{B}^{\prime}}\right)=1$

$F_{\mathrm{qd}}=1+2 \tan \varphi(1-\sin \varphi)^{2}\left(\frac{\text { Df }}{\mathrm{B}^{\prime}}\right)=1$

$\mathrm{F}_{\gamma \mathrm{d}}=1$

$\mathrm{F}_{\mathrm{ci}}=\left(1-\frac{\tan ^{-1}\left(\frac{\mathrm{Pa} \cos \alpha}{\sum_{\mathrm{i}=1} \mathrm{~V}}\right)}{90}\right)^{2}=0.996$

$\mathrm{F}_{\mathrm{q} i}=1$

$\mathrm{F}_{\gamma \mathrm{d}}=\left(1-\frac{\tan ^{-1}\left(\frac{\operatorname{Pa} \cos \alpha}{\sum_{\mathrm{i}=1} \mathrm{~V}}\right)}{\varnothing}\right)^{2}=0.988$

Ultimate bearing capacity:

$\mathrm{q}_{\mathrm{u}}=\mathrm{c} \mathrm{Nc} \mathrm{Fcd} \mathrm{Fci+q} \mathrm{Nq} \mathrm{Fqd} \mathrm{Fqi}+\frac{1}{2} \gamma$ B' $\mathrm{N} \gamma \mathrm{F} \gamma \mathrm{d}$ F $\gamma \mathrm{i}$

$\mathrm{q}_{\mathrm{u}}=399.61 \mathrm{ton} / \mathrm{m}^{2}$

Safety factor of soil:

$\mathrm{FS}=\frac{\mathrm{q}_{\mathrm{u}}}{\mathrm{q}_{\max }}=30.66>3$ 


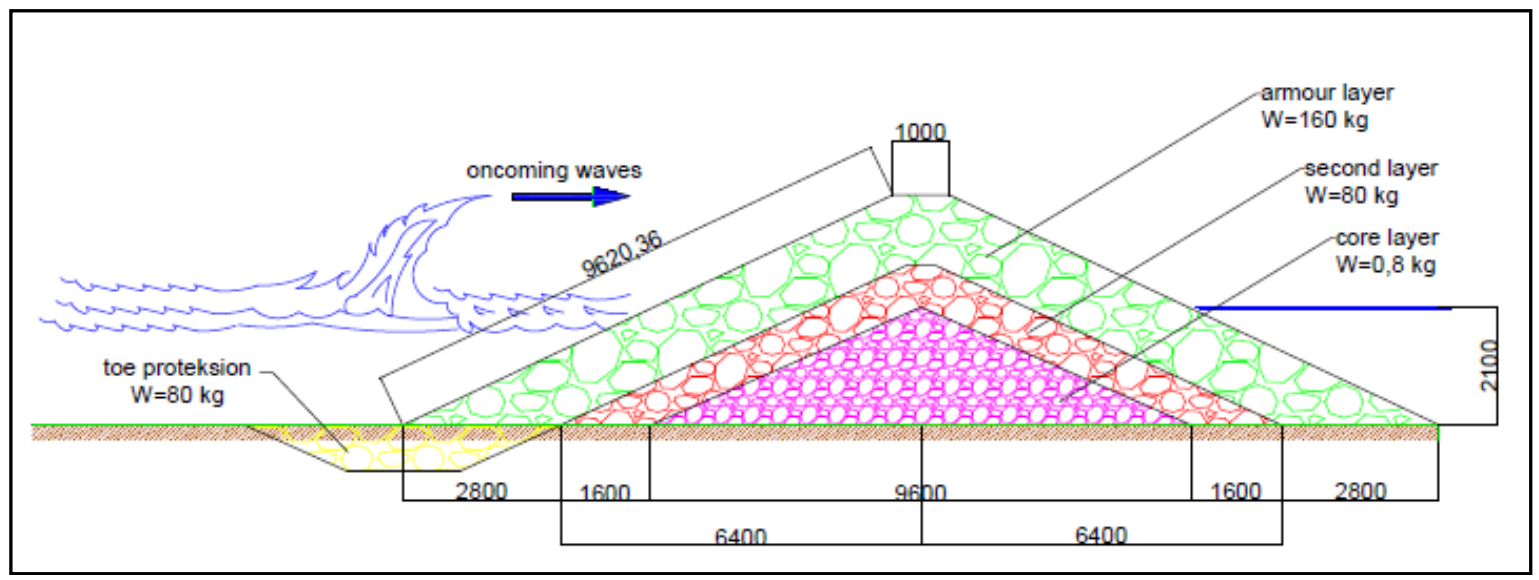

Figure 7. Groin Dimension

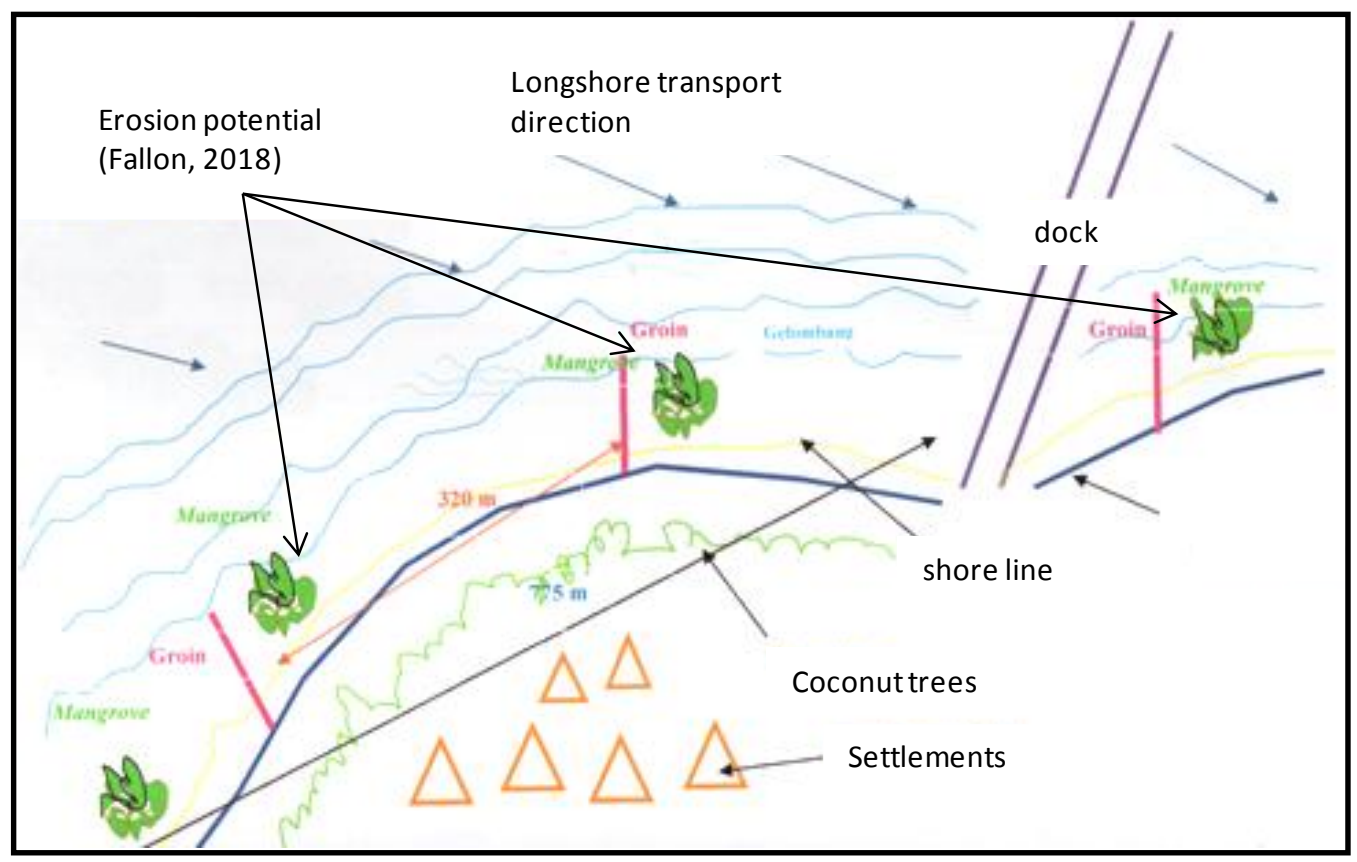

Figure 8. The Crucial Mangrove Planting Location to Prevent Erosion behind the Groin

\subsection{Mangrove Planting}

According to Fallon (2018), currents are created that move the sand in the same direction of wave resulting erosion behind the groin. To prevent erosion on the use of groin, mangrove planting is recommended at the location as shown in Figure 8.

\section{CONCLUSION}

Based on the results and discussion, the things that can be concluded are:

1. Dominant wind direction is south with a maximum wind speed of 33 knots or $16.962 \mathrm{~m} / \mathrm{s}$. Winds coming from the west, southwest, and southeast affect the analysis of wave forecasting. 
2. The height and depth of the breaking wave are $1.008 \mathrm{~m}$ and $1.29 \mathrm{~m}$, respectively.

3. Water level obtained from tidal data are HHWL $2.70 \mathrm{~m}$, MHWL $2.27 \mathrm{~m}$, MSL $1.39 \mathrm{~m}$, MLWL $0.51 \mathrm{~m}$, LLWL $-0.1 \mathrm{~m}$.

4. The sediment is classified as medium sand.

5. Based on the AHP method, structure used in order to prevent erosion is groin. The groin is combined with mangrove

6. The dimension and lay out of groin and mangrove are shown in Figure 7 and Figure 8.

\section{REFERENCES}

BNPB. (2018). (accessed: 21 September 2019) Data kejadian bencana abrasi, https://geospasial.bnpb.go.id/pantaua nbencana/data/dataabrasiall.php.

Chang, Y., Chu, K., \& Chuang, L.Z. (2018). Sustainable coastal zone planning based on historical coastline changes: A model from case study in Tainan, Taiwan. Landscape and Urban Planning, 174, 24-32.

Chen, C.H., Jiao, Z.L., \& Jiang, F.C. (2013). Navigational Environmental Risk Evaluation of Breakwater Based on the Analytic Hierarchy Process, Advanced Materials Research, 779-780, 648-1653.
CSE. (2013). Assessment of the Groin Fieldand Conceptual Plan for Groin Lengtheningat Edisto Beach, SC. Technical report. Coastal Science \& Engineering (CSE) PO Box 8056 Columbia SC 29202-8056.

Fallon, K.M. (2018). (accessed: 21 September 2019) Coastal Processes on Long Island: An Introduction to Erosion, Sea Grant on www.nyseagrant.org.

Hedge, A.V. (2010). Coastal erosion and mitigation methods-Global state of art. Indian Journal of Geo-Marine Science, 39(4), 521-530.

Hidayat, A. R. T., Wijayanti, W.P., Kurniati, S., \& Maha E.A. (2016). Challenge and opportunity of settlement and infrastructure development in the small island (case study: Pulau Laut Kelautan District, Kotabaru Regency), Procedia - Social and Behavioral Sciences, 227, 286-293.

Mangare, J. B. (2016). Penerapan Metode Analyical Hierarchy Process Untuk Pemilihan Sistem Pengamanan Pantai. Jurnal Sipil Statik, 4(11), 701-704.

Marfai, M. A. (2011). The hazardsof coastalerosionin Central Java, Indonesia: An overview. GEOGRAFIA, Malaysia Journal of Society and Space, 7(3), 1-9.

Hall, V.L., \& Ludwig, J.D. (1975) Evaluation of Potential Use of Vegetation for Erosion Abatement Along the Great Lakes Shoreline Miscellaneous Paper, Report No. 9604-003-17. Department of the Army Coastal Engineering Research Center (CERRE-EC) Kingman Building, Fort Belvoir. 
Pilkey O.H., \& Cooper J.A.G. (2012). "Alternative" Shoreline Erosion Control Devices: A Review. In: Cooper J., Pilkey O. (eds) Pitfalls of Shoreline Stabilization. Coastal Research Library, Vol 3. Springer, Dordrecht.

Plangiten, R. R. (2013). Pemilihan sistem

Pengamanan Pantai Dengan Menggunakan Metode Analytical Hierarchy Process (Studi Kasus: Pantai Wori di Kecamatan Wori Kabupaten Minahasa Utara). Jurnal Sipil Statik, 1(8), 579-586.

Triatmodjo, B. (2008). Teknik Pantai. Yogyakarta: Beta Offset. 